\title{
Det sønderjyske politiadjudantembedes arbejde
}

\author{
Ved Johan Hvidtfeldt.
}

Ved genforeningen blev der givet amtmandene i Nordslesviş ret vidtgående myndighed $i$ spørgsmål, der angik hehandlingen af det tyske mindretal eller var af betydning for opretholdelsen af ro og orden i granselandet. Denne myndighed var delvis begrundet $\mathrm{i}$ de almindelige lowbestemmelser, men blev også nærmere fastlagt $i$ forskellige instrukser til amtmænd og politimestre i Sønderjylland. Desuden var der i de første år efter 1920 en meget nøje kontakt mellem de fire nordslesvigske amtmænd, således at man ogsá på den måde kunne sikre sig, at man fulgte visse fxlles retningslinier $i$ behandlingen af de græensepolitiske spørgssmál.

I slutningen af tyverne og f $\phi$ rst $i$ trediverne blev de nationale forhold starkt tilspidset, og fra rigstysk side blev der sat mere og mere ind på at styrke det tyske mindretal, både $\emptyset$ konomisk og kulturelt. Efter nazismens sejr i Tyskland 1933 blev det hurtig klart, at man måtte regne med stigende aktivitet og angrebslyst fra tysk side, selvom de første år var præget af det tyske mindretals indre magtkamp. Det var under disse forhold af stor vigtighed for den danske regering at være $i$ besiddelse af den mest indgâende information om mindretallets arbejde, ligesom det var mere nødvendigt end nogensinde, at man fulgte den samme linie i de afg $\phi$ relser, som måtte træfles af landsdelens danske myndigheder i nationalpolitiske spørgsmål. Dette var bl. a. baggrunden for, at man oprettede en stilling som politiadjudant i de sønderjyske landsdele.

Den f $\varnothing$ rste politiadjudant blev politiassistent i København Fritz Jacobsen, som samtidig med sin udnevnelse til politi- 
mester i Åbenrå fik overdraget det nye hverv. Fritz Jacobsens personlige egenskaber gjorde ham særdeles velesnet til hvervet. Desværre fik han kun lov til i ganske kort tid at virke $i$ dette embede. Allerede den 4 . august 1935 døde han.

Kort tid efter havde amtmand Kr. Refslund Thomsen i Åbenrå en forhandling med justitsminister Steincke om ny-

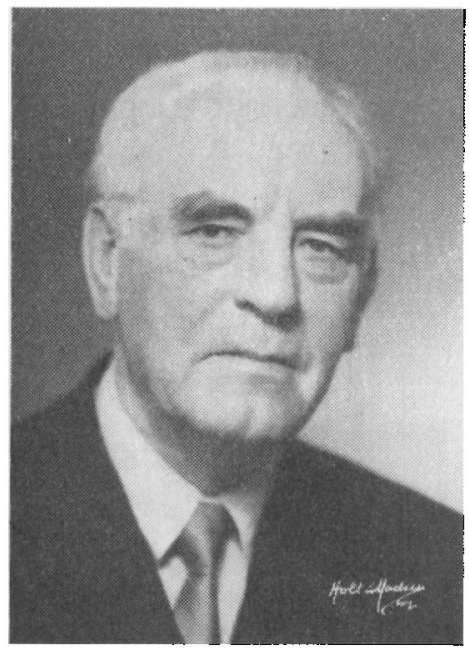

Kr. Kefslund Thomsen besættelsen. Den fik det for amtmanden overraskende forl $\varnothing b$, at Steincke opfordrede ham til selv at pătage sig hvervet. Refslund Thomsen afviste dog tanken. Da både justitsministeren og statsministeren $\emptyset$ nskede ham som politiadjudant, og hans svigerfader, H. P. Hanssen, rådede ham til at sige ja, måtte han dog tilsidst gå med til at efterkomme anmodningen.

Udnævnelsen til politiadjudant kom den 19. november 1935. Samme dag blev politimesteren i Åbenrå, A. A. Agersted, beskikket til at bistå amtmanden ved udf $\varnothing$ relsen af hans forretninger som politiadjudant, ligesom det blev bestemt, at kontorarbejdet skulle udf $\varnothing$ res af politimesterens kontor. I årene 1936-38 var cand. mag., senere professor, dr. phil. Troels Fink knyttet til embedet som sekretær. Da stillingen som politiadjudant var blevet suden indhold « efter tyskernes overfald pá det danske politi i september 1944, blev amtmand Refslund Thomsen den 28. september 1944 efter ansøgning fritaget for hvervet som politiadjudant. Samtidig bragte departementschef Svendsen på ministeriets vegne amtmanden en tak for hans store og fortjenstfulde virksomhed.

Der kan ikke være tvivl om, at Steincke så rigtigt. Nogen bedre mand end Refslund Thomsen kunne ikke tænkes. Fra sin pure ungdom havde han været med i det danske arbejde, og ingen kendte som han de nationalpolitiske problemer. Han var 
sammen med den senere kreditforeningsdirekt $\varnothing \mathbf{r}$ P. A. Call $\emptyset-$ af politiske grunde blevet bortvist fra latinskolen i Haderslev. Han blev derfor cand. polit fra Kobenhavns universitet i 1907. Efter et halvt års studium i Berlin blev han knyttet til "Hejmdal«, fra 1910 som redaktør. Fra 1908 var han konsulent for Vælgerforeningen og ledede dettes arbejdersekretariat, som ydede retshjælp til mindrebemidlede oğ på flere måder var en slags sekretariat for Vælgerforeningen. Stor betydning fik også de socialpolitiske kursus, hvor Callø sammen med Refslund Thomsen var den drivende kraft. En af de vigtigste opgaver i disse år f $\emptyset \mathbf{r}$ den første verdenskrig blev forberedelsen af rigsdagsvalget i 1912 og landdagsvalgene i 1908 og 1913. Disse valg viste en stor dansk fremgang. I Åbenrå amt havde der indtil 1908 været en stadig dansk tilbagegang. Ikke mindst her blev landdagsvalget i 1913 en strålende dansk sejr. Valğaftenen sendte H. V. Clausen et telegram til Refslund Thomsen: 》Victoria, Victoria, en ungdom dog bar sejren hjem, det skal vi aldrig glemme«.

Indtil 1915 fik Refslund Thomsen lov til fortsat at virke Sønderjylland. Så kom indkaldelsen til den tyske hær. Efter at være blevet såret blev han knyttet til civilforvaltningen i Königsberg og kunne først vende tilbage til Nordslesvig kort tid efter våbenstilstanden. Han kom straks ind i det nationalpolitiske arbejde på ny, blev medlem af kredsudvalget i Åbenrå og i 1920 landråd i Åbenrå, udpeget af den internationale kommission.

Det var naturligt, at han kort efter blev udpeget til at være den første danske amtmand i Åbenrå, en stilling han beklædte, indtil han i 1954 trak sig tilbage på grund af alder. Amtmandsembedet krævede en stor arbejdsindsats, som ikke blev mindre, efter at han i 1932 også var blevet amtmand over Sønderborg amt. De mange vigtige problemer, som måtte løses, ikke mindst i forbindelse med jernbanedrift og skolevæsen, kunne nok tage sin mand, men alligevel blev der kaldt på ham også fra anden side, således var han formand for den sønderjyske realkreditkommission, som blev nedsat i 1926.

Trods den store arbejdsbyrde blev der tid til med vågent $\emptyset j \mathrm{j}$ 
ợ vågent sind at følge med $\mathrm{i}$ den nationalpolitiske udvikling. Erfaring, viden og roligt omdømme var en god ballast for den, der skulle overtage ledelsen af politiadjudantembeãet.

Instruksen for den nye politiadjudant blev udstedt den 11. december 1935. Da den giver et indtryk af politiadjudantens arbejde og virkeområde, gengives et uddrag af den i det f $\varnothing$ lgende.

\section{Midlertidig Instruks}

for

Politiadjudanten $i$ de sønderjydske Landsdele.

Politiadjudanten i de sønderjydske Landsdele er direkte underlagt Justitsministeriet som Raadgiver i Sager angaaende grænsepolitiske Spørgsmaal. Han bistaas ved Udøvelsen af dette Hverv af Politimesteren i Aabenraa Købstad m. v., hvis Kontor udforer det med Stillingen forbundne Kontorarbejde.

Det paahviler i forste Rakke Politiadjudanten gemem Politimestrene og i Samarbejde med Amtmændene, Statsadvokaten og Centraladministrationen at samle alle Oplysninger om de sarlige sønderjydske Forhold og skabe en hurtigt virkende Oplysningscentral for Landsdelen under Anvendelse af Person- og Sagkartoteker .....

I Tilfælde af Uroligheder, Demonstrationer o. lign., hvor der bliver Spørgsmaal om Anvendelse af større Politistyrker, har Politiadjudanten Dispositionsret over det i Landsdelen stationerede Politi. Ved Uroligheder af denne Art bor Politimesteren i Aabenraa K $\varnothing$ bstad n. v. personlig være til Stede paa Politiadjudantens Vegne og $\mathrm{i}$ det Omfang, han finder det nødvendigt, lede Politiets Bevigelser i Marken.

For at opnaa ensartede Afgørelser i Sager af grænsepolitisk Art saasom angaaende Flagning, Processioner eller Optræden af udenlandske Talere her i Landet, har Justitsministeriet paalagt Politimestrene $\mathrm{i}$ de sønderjydske Landsdele at indsende Indstillinger i saadanne Sager til Politiadjudanten, der derefter traffer Afgorelse i Sagerne eventuelt efter Forhandling med vedkommende Amtmand.

I Trivlstilfalde forelægges Sagen for Justitsministeriet. Det paahviler Politiadjudanten at drage Omsorg for, at Politimestre- 
ne i de s $\phi$ nderjydske Landsdele følger ensartede Retningslinier i Sager af den næevnte Art, og Politiadjudanten bør til Opnaaelse af dette Formaal forhandle med Politimestrene.

Sager angaaende Opholds- og Arbejdstilladelse for udenlandske Statsborgere i de sønderjydske Landsdele indsendes til Politiadjudanten, der forelægger dem for Chefen for Statspolitiet $\ldots$...

Justitsministeriet, den 11. December 1935.

S t e i n c k e.

/ Colov.

På de fleste punkter var amtmand Refslund Thomsens instruks enslydende med Fritz Jacobsens, der var udstedt 12. januar 1935. Dog har de nye forhold selvf $\phi$ lgelig medf $\phi \mathbf{r t}$ visse andringer af mere formel karakter. I afsnittet om afgørelse i sager af grænsepolitisk art hed det således i den ældre instruks, at disse af politiadjudanten skulle forelægges for amtet. Hvis sagen var af »særdeles hastende karakter « kunne politimesteren indsende sagen direkte til amtmanden, altså uden først at sende den til politiadjudanten. Havde der fundet mundtlig forhandling sted med denne, skulle der dog gives oplysning om hans standpunkt, og genpart af indstillingen skulle sendes til politiadjudanten. I $\varnothing$ vrigt hed det, at sager vedrørende disse spørgsmål skulle forelægges justitsministeriet til af $₫ \phi$ relse, hvis amtet ikke kunne tiltræde politiadjudantens indstilling.

En stor del af embedets opgaver bestod i at holde regeringen og administrationen orienteret om det tyske mindretals virksomhed og de grænsepolitiske forhold. Det skete dels gennem løbende beretninger, dels gennem store samlede oversigter over forholdene eller over enkelte, særligt vigtige problemer. Disse store indberetninger, som nu findes i justitsministeriets arkiv, har idag deres særlige værdi ved at fortælle eftertiden, hvor vel informeret politiadjudanten og hans medarbejdere var, hvor godt man fuigte med fra dansk side, og hvorledes forudsætningerne var for de grænsepolitiske afgørelser, der blev truffet, og den nationalpolitiske linie, der blev fulgt. Af disse store indberetninger er der isar grund til at nævne folgende: 
a) Indberetning af 30. juni 1936 om det tyske udlandsarbejde i Nordslesvig, trykt i Sønderjyske årbøger 1946, s. 1-17.

b) Beretning af juni 1937. Hovedafsnittene er: 1. Den politiske udvikling efter 1920. 2. Økonomiske og sociale forhold. 3. De kulturelle forhold. Ialt 123 sider.

c) Redegørelse for jordspørgsmålet i Sønderjylland, indsendt 8 . januar 1938. Hovedsagelig udarbejdet af kreditforeningsdirekt $\phi r$ P. A. Callф, Haderslev. Ialt 35 sider.

d) Beretning af juli 1938 med samme afsnit som beretningen fra det foregående år. 100 sider.

e) Beretning om skoleforholdene i de søonderjyske landsdele 1920-38. 51 sider.

Beretningerne under b), d) og e) er udarbejdet med bistand af sekretaren, senere professor, dr. Troels Fink.

f) De kirkelige forhold $i$ de sønderjyske landsdele i nationalpolitisk belysning, udarbejdet $\mathrm{i}$ november 1938 af dommer Asger Rasmussen i Rødding, som tidligere havde været stiftsfuldmægtig i Haderslev. 108 sider.

s) Beretning af december 1938 om stemningen på dansk og tysk side efter indlemmelsen af $\emptyset_{\text {strig }}$ og Sudeterlandet. 11 sider.

I denne oversigt er den første af de større indberetninger, fra maj 1936, ikke medtaget, idet den gengives $i$ det følgende. Den giver en prøve på disse indberetningers karakter og et indtryk af, hvor stor viden man sad inde med. Den er dog ret kort, sammenlignet med de store indberetuinger fra de følgende år. En særlig værdi får den ved at give et rids af arbejdsplanen for politiadjudantembedets fremtidige arbejde, således at man derigennem kan få et indtryk af, hvad politiadjudanten beskæftigede sig med, og hvorledes en del af arbejdet blev lagt til rette. 


\section{Indberetning fra politiadjudanten maj 1936.}

I Justitsministeriets Instruks for Politiadjudanten i de sønderjydske Landsdele ... hedder det ...1)

Der er i denne Anledning paa Politiadjudantkontoret i den forløbne Tid ved Siden af Fremskaffelsen af Oplysninger til Behandlingen af de løbende Sager anlagt f $\phi$ lgende Kartoteker:

1) Et specielt Kartotek over samtlige Personer med Opholdsresp. A rbejdstilladelse (endnu ikke færdigt).

2) Et Kartotek omfattende samtlige Personer, der er næevnt i Sager, der passerer eller behandles paa Politiadjudantkontoret (»Hovedkartotek»).

3) Et Specialkartotek over Personer tilhørende yderliggaaende politiske Fraktioner.

4) Et »Emnekartotek" vedrørende Spфrgsmaal af gransepolitisk Betydning.

Materialet til disse Kartoteker fremskaffes dels ved Informationer, som Politiet selv fremskaffer, dels ved Udnyttelse af de Oplysninger, der fremkommer i Pressen.

Maa det end siges at være af Betydning, at Oplysninger som de ovennæunte indsamles og registreres, saaledes at der, naar der $\emptyset$ nskes Oplysninger om en Person eller en Sag, omgaaende kan fremskaffes saadanne, vilde det dog være af end st $\phi$ rre Betydning, om Kontorets Arbejde kunde udformes til en planmæssig Overvaagelse af og Kontrol med det tyske Arbejde $i$ alle dets Forgreninger.

Der kan formentlig ikke være Tvivl om, at vi i de sdj. Landsdele staar overfor et maalbevidst tysk Arbejde, som har til Formaal efterhaanden at forskyde Sindelagsgrænsen nordpaa og derved skabe Betingelserne for en Grænserevision. Det tyske Arbejde er saa meget farligere, som det ikke saa meget har sin Rod i selve Mindretallet, men ledes og financieres sydfra, dels af store tyske Organisationer som »Verein für das Deutschtum im Auslande" og andre Organisationer af beslægtet Karakter, dels af tyske Kommuner (Sogneraad - Byraad - Amtsraad), Enkeltstater og selve det tyske Rige.

1) Herefter gengives en del af instruksen af 11. dec. 1935. 
A.

Det politiske Arbejde

Det tyske Arbejde i de sønderjydske Landsdele kan inddeles i tre Grupper: 1. det politiske, 2. det фkonomiske og 3. det kulturelle. Det politiske Arbejde varetoges indtil Nationalsocialisternes Overtagelse af Regeringsmagten i Tyskland af »Schleswigscher Wählerverein«, der var en hele Landsdelen omfattende politisk Organisation. Den valgte som andre politiske Foreninger selv sin Bestyrelse (siden Genforeningen har Folketingsmand Pastor Schmidt, 'Tønder, varet Foreningens Formand), fastsatte Retningslinjerne for det tyske Arbejde, i hvilken Henseende der kan henvises til en Række politiske Programudtalelser, og udpegede Folketingkandidaterne. Det vides ikke, om der er tilflydt denne Organisation som saadan Statsmidler sydfra i Tiden før Nationalsocialismens Gennembrud. Men Mindretallets Repræsentant i den danske Rigsdag har i hvert Fald fra Begyndelsen af 1920'erne modtaget en aarlig Underst $\varphi$ ttelse af det tyske Rige paa 4-6000 Kroner, hvorhos der gentagende er ydet ham Hjælp af tyske offentlige Midler til hans Sønners Bosættelse paa en Gaard i Kværs Sogn i Aabenraa Amt. Endvidere vides, at forskellige af de »Bevægelser«, der har varet i Nordslesvig, er blevet støttet med tyske offentlige Midler. Det galdersaaledes Lei-Bevægelsen.

Efter Nationalsocialismens Gennembrud i det tredie Rige overf $\phi$ rtes de nazistiske Organisationsformer til Nordslesvig. Vi fik vort N.S.A.N. med brune Stormtropper, Marine- og Motorstorme, særlige Kvinde- og Ungdomsorganisationer, alt som direkte Underafdelinger af de tilsvarende rigstyske Organisationer. Stormtropperne er senere efter Ordre fra det brune Hus i München -- blevet opløst, men umiddelbart derefter oprettedes de endnu bestaaende »Kammeradschaften\&; det var saaledes nærmest en Navneforandring, der fandt Sted. En Følge af Mindretallets Nazificering blev, at Mindretallet politisk kom under rigstysk Overledelse. Der blev syd for Gransen oprettet et saakaldt lille og stort Raad med Overpresident Lohse i Spidsen og i $\varnothing v r i g t$ bestaaende af ledende Nazister og Embedsmand, som ikke blot udnævnte den saakaldte »Landesführer«, som Mindretallet maatte adlyde, men tillige udfærdigede Retningslinjer for 
Mindretallets Arbejde og afgjorde forekommende Konflikter. De sørgelige Erfaringer, der blev gjort, ikke blot med de hurtigt skiftende »Landesführere«, men ogsaa med Hensyn til den Splid, der skabtes indenfor Mindretallet, har haft til Følge, at man vistnok er blevet mere forsigtig med sydfra at ville dirigere Udviklingen nord for Græusen. Men da det politiske Arbejde i dets forskellige Forgreninger og Opretholdelsen af Mindretal. lets Presseorgan »Nordschleswigsche Zeitung « er forbundet med betydelige Udgifter, vil den, der skal tilvejebringe de nødvendige Pengemidler, altid kunne udøve en betydelig Indflydelse. I den standende Strid mellem de forskellige Retninger indenfor det nazificerede Mindretal fremkommer jaevnligt Hentydninger til, at den og den Person menes at have Bevaagenhed sydfra og dermed Adgang til Pengekassen.

Der kan ikke vare Tvivl on, at det mat vere Politiadjudantens Opgave med Politimesterens Bistand nøje at overvaage Ldviklingen i Mindretallets politiske Virke, efterspore Forbindelserne over Gransen, søge at komme til Klarhed over, hvilke Direktiver der sydfra gives Mindretallet, og hvilke Pengemidler der stilles til Raadighed. Det maa vaere Formaalet at holde Regeringen underrettet om alle herhenhфrende Foreteelser, saa der til enhver Tid kan foreligge et muligt sikkert Grundlag til Bedømmelse af Begivenhederne. Det tyske Arbejde i vort Granseland er Led i et tilsvarende Arbejde $i$ alle de Lande og Granselande, som efter den stortyske Tanke, som det tyske Folk i de sidste 10-15 Aar systematisk er opdraget til at tro paa, bor forenes med Tyskland. Det har hos os ikke formatet at gribe forstyrrende ind i Udviklingen i tilnarmelsesvis samme Grad som i andre Grænsedistrikter, der omfatter tyske Mindretal. Men de Metoder, der praktiseres fra tysk Side, navnlig da efter Nazificeringen, er ofte af en [saadan] Karakter, at det maa betegnes som nødvendigt at holde sig n $\emptyset$ je underrettet, hvis man skal liunne gøre sigs Haab om i givet Tilfalde at imфdegaa dem paa rette Maade.

Som praktiske Forslag til Opnaaelse af Overblik over og Indblik i det tyske Arbejde paa politisk (Omraade anføres: 1) Der traffes Aftale med Det sønderjydske Iandsbibliotek om, at 
Biblioteket abonnerer paa et à to slesvig-holstenske Dagblade, enkelte af de vigtigere tyske Tidsskrifter, der fortrinsvis beskæftiger sig med »udlandstyske» Spørgsmaal, en tyskskrevet Korrespondance fra Danzig, der giver Oplysning om det tyske Arbejde i Polen samt et tysk Dagblad eller Tidsskrift fra Czechoslovakiet. Biblioteket har erklæret sig villig til efter nærmere Aftale at anskaffe den Litteratur, der maatte onskes, og vederlagsfrit stille den til Raadighed for Politiadjudantkontoret. 2) Der anlægges særlige Akter for de vigtigste grænsepolitiske Organisationer syd for Grænsen, f. Eks. »Ausschuss zur Förderung der kirchlichen Bedienung der deutschen Minderheit in Nordschleswig«, »Wohlfahrts- und Schulverein für Nordschleswig « i Flensborg, »Schleswig-Holsteinerbund «, »Volksbund für das Deutschtum im Auslande« (V.D.A.), »Auslandinstitut« i Stuttgart, »Deutscher Schutzbund «, »Verein heimattreuer Nordschleswiger « samt for alle politiske Organisationer i Nordslesvig, hvortil henregnes

》Schleswigscher Wählerverein *

$\gg$ Nationalsocialistische Arbeitsgemeinschaft Nordschleswig« (N.S.A.N.)

»Nationalsocialistische Deutsche Arbeiterpartei Nordschleswig (N.S.D.A.P.N.)

"Schleswigsche Kameradschaft $\ll$

»Nordschleswigsche Frauenschaft «

»Deutsche Mädchenschaft Nordschleswig«

»Deutsche Jungenschaft Nordschleswig«

"Verband ehemaliger deutscher Soldaten im abgetretenen

Nordschleswig\&

$\gg$ Deutsche Selbsthilfe $\ll$.

I disse Akter gives - evtl. med Henvisning til Kartoteket et kortfattet Referat af, hvad der Tid efter anden fremkommer af Meddelelser om de paagaldende Foreninger, saaledes at man i Kontorets Aarsberetning kan give en Oversigt over Foreningernes Virksomhed. Ud over de Oplysninger, der er Offentligheden tilgængelig, s $\emptyset$ ges fremskaffet Oplysninger ogsaa om Forhold, der hemmeligholdes, $i$ hvilken Henseende navnlig anføres Forbindelserne over Grænsen. 
B.

\section{Det фkonomiske Arbejde}

Til de særlige s $\varnothing$ nderjydske Forhold, som Politiadjudanten efter Instruksen skal indsamle alle Oplysninger om og skabe en hurtigt virkende Oplysningscentral for, maa efter min Mening ogsaa henregnes den $\varnothing$ konomiske Side af det tyske Arbejde, og jeg skal i det følgende ogsaa fremsætte nogle Bemærkninger derom.

Paa det $\phi$ konomiske Omraade m $\phi$ der vi f $\phi$ rst Arbejdsfronten, der er et Led i den almindelige tyske af Dr. Ley ledede Arbejdsfront og er underlast et særligt Kontor for Udlandet i Hamborg. I Nordslesvig, hvor Arbejdsfronten er organiseret $i$ »Ortsgruppen $\&$ og $\gg$ Stützpunkte «, findes Filialkontorer af Arbejdsfronten $i$ Aabenraa, S $\phi$ nderborg, Haderslev, T $\phi$ nder, H $\phi j e r$, Tinglev, Graasten ug L $\emptyset$ gumkloster. Den tidligere »Deutsch-nationaler Handlungsgehilfenverein «, der svarede til den danske Handels- og Kontoristforening, er indlemmet i Arbejdsfronten, der saaledes omfatter Arbejdere og Funktionærer. Ogsaa Arbejdsgiverne er forфvrigt tilsluttet Arbejdsfronten. Der har i den sidste Tid kunnet spores en stigende Aktivitet indenfor den tyske Arbejdsfront $i$ Nordslesvig baade med Hensyn til at skaffe Larlinge, Funktionærer og Arbejdere Pladser, men ogsaa m. H. t. Boykotningstendenser overfor Arbejdere og Forretningsdrivende.

I nær Tilslutning til Arbejdsfrontens Organisationer virker Haandværkerorganisationer, der ledes af et saakaldt 》Raadgiverkontor for Haandværket « i Aabenraa med ti Filialkontorer rundt omkring i Nordslesvig. Een à to Gange ugentlig mфder Haandværkerkonsulenten, Hr. B $\phi s e$, der arbejder i Tilslutning til Haandværkerkamret i Flensborg, for at staa Haandværkere, der maatte ops $\varnothing$ ge ham, bi med Raad og Daad. Der kan ydes Haandværkere Laan. Tingbogsbladet viser, at disse Laan ydes gennem Kontorchef Jessen, der er Prokurist i »Kreditanstalt Vogelgesang «. Endvidere kan anføres, at der som Led i dette Arbejde til Styrkelse af den tyske Haandværkerstand i Nordslesvig ogsaa ydes Hjælp til unge Haandværkeres Uddannelse i Tyskland. Et Lærlingeanvisningskontor tager sig af at skaffe de Unge Pladser. 
I Aabenraa er endvidere oprettet et Raadgivningskontor for Landmiend, ledet af den bekendte Dr. Lorenz Christensen, som bl. a. har forsogt at skabe sig en Position ved at varetage den tyske Befolknings Interesser overfor danske Kreditinstitutioner. Det er mig ikke bekendt, om der er nogen Forbindelse mellem dette Kontor og de tyske Landboforeninger og deres Fællesorganisationer (»Landwirtschaftlicher Hauptverein für Nordschleswig «), hvis Formand er Gaardejer Diedrichsen, Bodskov. Der er i $\phi v r i g t$ tyske Landboforeninger i Haderslev Amt, Aabenraa Amt, S $\phi$ nderborg Amt, T $\phi$ nder Amt, L $\phi$ gumkloster og Omegn og Tinglev og Omegn. De tyske Landboforeninger har deres 'gne Konsulenter. De er tilsluttet Landbrugskammeret i Kiel, der formentlig i betydeligt Omfang financierer deres Arbejde.

Endelig b $\phi \mathbf{r}$ blandt de $\phi k$ onomiske Organisationer nævnes den i 1926 i Berlin oprettede »Kreditanstalt Vogelgesang«, af hvis Aktiekapital kun $45.000 \mathrm{Kr}$. er tegnet af Privatmænd og Privatbanker, medens det ti-dobbelte Beløb stammer fra tyske Statsbevillinger. For saa vidt det siges, at Aktietegningen er sket af Privatbanker og Privatpersoner i Ind-og Udland, er dette formelt rigtigt. For at tilslфre den virkelige Kilde lader man forskellige Pengeinstitutter i Ind- og Udland, f. Eks. "Tysk RentenbankKreditanstalt « og »Hollandbank " i Amsterdam, fungere som Straamænd. Men Pengene hidrører fra Statsbevillinger og officielle Fonds. Fra Statsbevillinger stammer endvidere den for faa Aar siden foretagne Fornyelse af Aktiekapitalen med yderligere $450.000 \mathrm{Kr}$. og den Indskudskapital paa 5-6 Millioner, som Kreditanstalten har at arbejde med. Hidtil har Vogelgesang if $\emptyset$ lge Tinglysningsbladet faaet Skøde paa 121 Grundejendomme, deraf 88 selvstændige Landejendomme. For at faa disse mange Ejendomme forvaltet er der blevet oprettet et sakaldt Höfeverwaltungsgesellschaft $i$ Haderslev med en Aktiekapital paa 250.000 Kroner. Formaalet med det store Opk $\phi b$ af nordslesvigsk Jord er, som $\mathrm{Hr}$. Vogelgesang selv har udtalt offentligt i 1926, at 》opmagasinere Jord til senere Udstykning«. I Kraft af $\sin$ Udlaansvirksomhed har Kreditanstalt Vogelgesang desuden Magten over et stort Antal Ejendomme i vort Grænseomraade. 
Det vilde efter min Mening vare meget onskeligh, om Politiadjudantkontoret ogsaa kunde paatage sig den Opgave at folge Udviklingen i det foranstaaende skitserede $\varnothing$ konomiske Arbejde. Selv om ogsaa andre Institutioner indsamler og ligger inde med Oplysninger specielt om Vogelgesangs Virksomhed, synes en Samling her ogsaa at kunne vare formaalstjenlig. Hvad Jordspørgsmaalet iøvrigt angaar, er det mig bekendt, at der fra anden Side føres en Aarsstatistik, hvis Resultater man muligt kunde fara opgivet og indf $\phi j \mathrm{jel} i$ en eventuel Aarsberetning.

Med Hensyn til Arbejdets Tilrettelarggelse henvises til det under $A$ in fine anf $\phi$ rte, der her mat kunne tages som Rettesnor.

C.

\section{Det kulturelle Arbejde}

Til de særlige şinderjydske Forhold, som Politiadjudanten skal skabe en Oplysningscentral for, maa efter min Mening ogsaa henregnes det omfattende Arbejde, som fra tysk Side udfoldes paa kulturelt Omraade. Det synligste Udslag af det kulturelle Arbejde er Oprettelsen af de mange tyske Privatskoler. Der er siden Genforeningen oprettet 53 tyske Privatskoler med et samlet Lærerpersonale paa mellem 80 og 90 Personer, hvoraf kun et lille Mindretal har dansk Indfødsret. I'engene til Lærerlønninger, som lavt beregnet udgør mindst 1/4 Million Kroner aarlig, kommer sydfra, formentlig gennem den nu af Redakt $\not)^{\circ}$ Ernst Schrøder i Flensborg ledede »Schul- und Wohlfahrtsverein Nordschleswig «, der atter financieres af det tyske Rige. Larerne ved de tyske Privatskoler, men for $\phi$ vrigt ogsaa de tysksprogede offentlige Skoler er organiseret $i$ »Deutscher Lehrerverein für Nordschleswig«, der staar i intim Forbindelse med den nationalsocialistiske Organisation i 'Tyskland. For Pengene sydfra er ogsaa de mange tyske Skolelygninger i Nordslesvig opf $\varnothing$ rt. De er indrettet saaledes, at de ogsaa kan anvendes som Forsamlingshuse. De tyske Skoleforeninger i Nordslesvig, der formelt staar som Barere af de tyske Privatskoler, er sammensluttet i »Deutscher Schulverein für Nordschleswig«, der har Kontor i Tinglev og ledes af Rektor Koopmann. 
Men det kulturelle Arbejde kan tillige paavises paa mange andre Omraader. Der er siden Genforeningen oprettet 49 tyske Folkebogsamlinger, som ledes af en Central i Aabenraa og" opretholdes ved Hjælp af Penge sydfra. Endvidere kan nævnes den tyske Frimenighedsbevægelse. Der er oprettet 6 Frimenigheder, bygget anselige Præstegaarde til Præsterne og stillet Biler til deres Raadighed. Frimenighedspræsterne har i 1935 kunnet afholde Gudstjeneste i 46 nordslesvigske Sognekirker, deriblandt adskillige, hvor der aldrig er bleven holdt tysk Gudstjeneste $i$ den tyske Tid. De tyske Frimenigheder er sammensluttet $i$ en »Nordschleswigsche Gemeinde in der evangelisch-lutherischen Landeskirche Schleswig-Holsteins med H. B. Jepsen, Tinglev, som Formand. De maa i det hele betegnes som værende Led i den slesvig-holstenske Landskirke, der efter Ensretningen i Tyskland er gaaet op i den tyske Rigskirke. I denne Forbindelse kan ogsaa henvises til det tyske Velgørenhedsarbejde, der dels ledes af lokale tyske Kvindeforeninger (sammensluttede $\mathrm{i}$ ฟerband deutscher Frauenvereine«), dels dirigeres af 》Wohlfahrtsdienst Nordschleswig» i Tinglev, der formentlig er at anse for en Underafdeling af »Wohlfahrts- und Schulverein für Nordschleswig i Flensborg.

»Wohlfahrtsdienst《 befatter sig navnlig med Organisationen af den tyske Sygepleje.

En betydelig Virksomhed udfoldes af »Deutscher Kulturbund $\ll$ og beslægtede Foreninger ved afholdelse af Foredrag, Tilrettelæggelse af Teaterforestillinger, Koncerter m. v., hvor fremragende Kræfter sydfra stilles gratis til Disposition. Endvidere kan nævnes de mange Fællesrejser til Tyskland, der ordnes baade for Børn og Voksne ved »Kraft durch Freude» og andre Organisationer.

Der skal endelig ogsaa henvises til de mange Fadderskaber, der i de sidste Aar har støttet saa godt som alle Grene af det tyske Arbejde i Nordslesvig.

Det gælder om adskilligt af det $i$ foranstaaende Afsnit næunte, at andre Myndigheder i Embeds Medf $\phi r$ maa følge Udviklingen. I Skoledirektionernes Beretninger vil findes Oplysninger om de tyske Privatskoler, forsaavidt Antallet af disse og 
Børneantallet angaar. De kirkelige Myndigheder vil formentlig ogsaa til en vis Grad fø̆lge Frimenighedsbevagelsen. De Oplysninger, der tilvejebringes ad denne Vej, vil man formentlig kunne faa stillet til Raadighed og benytte. Men der er baade ved det tyske Privatskolevæsen og den tyske Frimenighedsbevægelse Sider, som de nævnte Myndigheder ikke befatter sig med, i hvilken Forbindelse navnlig anføres Tilknytningen til Myndigheder og Institutioner syd for Grænsen, som det maa have den allerstørste Interesse at faa Klarhed over. Jeg maa derfor mene, at ogsaa det kulturelle Arbejde i dets fulde Omfang $b \phi \mathbf{r}$ f $\phi$ lges af Politiadjudantkontoret, saaledes at der paa dette Sted samles Oplysninger om det tyske Arbejde i alle dets Forgreninger. Med Hensyn til Arbejdets Tilrettelæggelse skal jeg ogsaa her indskrænke mig til at henvise til det under $A$ in fine anførte.

Ved en Samling af det $\mathbf{i}$ foranstaaende skitserede Materiale vil det i højere Grad, end det hidtil har været Tilfældet, være mulist at faa Overblik over det tyske Arbejde, et Overblik, som det hidtil har skortet paa, netop fordi Oplysningerne var spredt og ikke blev gjort til Genstand for en systematisk Bearbejdelse. Samles Materialet, vil der tillige kunne skabes Muligheder for en dybere Indsigt, idet Stoffets Bearbejdelse vil lede paa Sporet efter Oplysninger, som ikke uden videre kan ses af offentlig tilgængelige Kilder. Jeg tror derfor, det vilde være af overordentlig stor Betydning, om den $\mathrm{i}$ foranstaaende skitserede Opgave kunde blive taget op. 